\title{
Redescription of Asemonea cristata Thorell, 1895 (Araneae: Salticidae: Asemoneinae), with notes on its synonymy and distribution
}

\section{Переописание Asemonea cristata Thorell, 1895 (Araneae: Salticidae: Asemoneinae), с заметками о его синонимии и распространении}

\author{
Puthoor Pattammal Sudhin ${ }^{1,}$, Karunnappilli Shamsudheen Nafin ${ }^{1}$, \\ John T.D. Caleb ${ }^{2}$, Ambalaparambil Vasu Sudhikumar ${ }^{1}$ \\ Патур Патаммах Судхин ${ }^{1,}$, Карунаппияи Шамсудхин Нафин ${ }^{1}$, \\ Ажкон Т.А. Калеб², Амбалапарамбия Васу Судхикумар ${ }^{1}$
}

\footnotetext{
${ }^{1}$ Centre for Animal Taxonomy and Ecology, Department of Zoology, Christ College (Autonomous), Irinjalakuda - 680 125, Kerala, India. 2 Zoological Survey of India, Prani Vigyan Bhavan, M-Block, New Alipore, Kolkata - 700 053, West Bengal, India.

"Corresponding author; e-mail: sudhinpp@gmail.com
}

KEY WORDS: Aranei, jumping spider, Western Ghats, Wayanad Wildlife Sanctuary.

КЛЮЧЕВЫЕ СЛОВА: Aranei, паук-скакунчик, Западные Гаты, заповедник Вэйнард.

ABSTRACT. Asemonea cristata Thorell, 1895 is redescribed on the basis of newly collected materials from the Western Ghats region, Kerala, India. Asemonea picta Thorell, 1895 and A. santinagarensis (Biswas et Biswas, 1992) are synonymised with $A$. cristata. Collecting localities of $A$. cristata are mapped as well.

How to cite this article: Sudhin P.P., Nafin K.S., Caleb J.T.D., Sudhikumar A.V. 2020. Redescription of Asemonea cristata Thorell, 1895 (Araneae: Salticidae: Asemoneinae), with notes on its synonymy and distribution // Arthropoda Selecta. Vol.29. No.2. P.251256. doi: 10.15298/arthsel. 29.2.11

РЕЗЮМЕ. Asemonea cristata Thorell, 1895 переописан по свежесобранным материалам из региона Западные Гаты, Керала, Индия. Asemonea picta Thorell, 1895 и A. santinagarensis (Biswas et Biswas, 1992) синонимизированы с $A$. cristata. Также прокартированы точки находок $A$. cristata.

\section{Introduction}

The jumping spider genus Asemonea O. PickardCambridge, 1869 currently comprises 25 valid species distributed mainly in Africa and Asia [WSC, 2020]. Members of this genus are small, often green or yellowish, and are usually found among leaves [Wesołowska, 2009]. Asemonea cristata Thorell, 1895 was described from a single male from Tharrawady in Burma (now Myanmar). We have collected the male and female of $A$. cristata during a three year long field survey in the Wayanad Wildlife Sanctuary, a part of the Southern Western Ghats of India. In the present paper, we redescribe both sexes of $A$. cristata on the basis of the fresh material. Additionally, we argue that the names Asemonea picta Thorell, 1895 and A. santinagarensis (Biswas et Biswas, 1992) are to be synonymised with $A$. cristata. The current geographic distribution of the species is mapped as well.

\section{Materials and methods}

Photos of live specimens were taken with a Canon EOS 5D Mark-III using Canon EF $100 \mathrm{~mm}$ f/2.8 Macro USM Lens, Canon MP-E 65mm 1-5x Macro Lens and Canon MT-24EX Macro Twin Lite Flash. Spiders were collected by beating vegetation and the collected specimens were stored in $70 \%$ ethanol. Morphological examination was undertaken under a Leica M205 C stereomicroscope. The digital images were taken by means of Leica DMC4500 digital camera attached to Leica M205 C stereomicroscope, with the software package Leica Application Suite (LAS), version 4.3.0. LAS montage facility. All measurements are in $\mathrm{mm}$. Measurement data for palps and legs are as follows: total length [femur, patella, tibia, metatarsus (except palp), tarsus]. The terminology follows Wanless [1980]; for leg spination the format by Bossellaers \& Jocque [2000] is followed. The studied specimens are deposited in the reference collection at the Centre for Animal Taxonomy and Ecology (CATE), Department of Zoology, Christ College (Autonomous), Irinjalakuda, Kerala, India.

Abbreviations used in the text and figures are as follows: a - atrium, ALE - anterior lateral eye, AME - anterior median eye, D - described, da — dorsal apophysis, co copulatory opening, do - dorsal, e - embolus, f - distal flange, fa - femoral apophysis, fd - fertilization duct, $\mathrm{pl}$ prolateral, PLE - posterior lateral eyes, PME - posterior median eyes, plv - prolateral ventral, $\mathrm{rl}$ - retrolateral, RTA - retrolateral tibial apophysis, rlv — retrolateral ventral, st - subtegulum, $\mathrm{t}$ - tegulum, $\mathrm{v}$ - ventral, ZSI The Zoological Survey of India, Kolkata. 


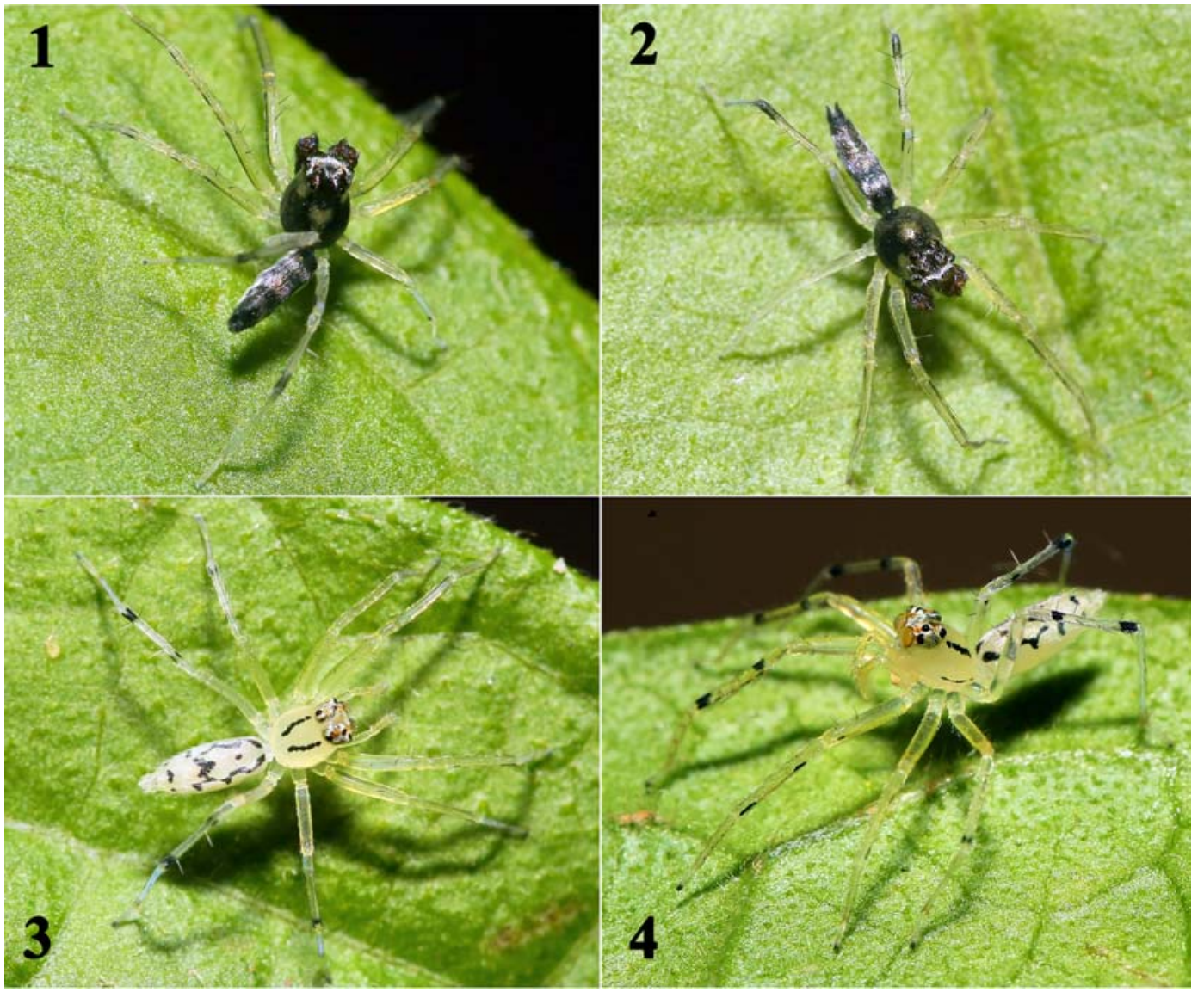

Figs 1-4. General appearance of Asemonea cristata Thorell, 1895 from the Wayanad Wildlife Sanctuary, Kerala, India: 1-2 — male, dorsal view; 3 - female, dorsal view, 4 - ditto, lateral view.

Рис. 1-4. Общий вид Asemonea cristata Thorell, 1895 из щзаповедника Вэйнард, Керала, Индия: 1-2 — самец, вид сверху; 3 самка, вид сверху, 4 - то же, сбоку.

\section{Taxonomy}

Asemonea cristata Thorell, 1895

Figs 1-25, Map.

Asemonea cristata Thorell, 1895: 316 (D $\sigma^{7}$; holotype $\sigma^{7}$ in the Natural History Museum, London, UK, not examined).

Asemonea cristata: Simon, 1901: 396; Sherriffs, 1931: 537-

538; Bonnet, 1955: 763; Wanless, 1980: 242, figs 19A-E.

Asamonea cristata: Roewer, 1954: 927.

Asemonea picta Thorell, 1895: 318 (D+; lectotype ${ }_{+}$in the Natural History Museum, London, UK, not examined). Syn.n. Asemonea picta: Simon, 1901: 396; Sherriffs, 1931: 538; Bon-

net, 1955: 764; Wanless, 1980: 243, figs 20A-C.

Asamonea picta: Roewer, 1954: 927.

Lyssomanes santinagarensis Biswas et Biswas, 1992: 386, figs 17-19 (D ${ }_{+}$; holotype + in ZSI, examined). Syn.n.

Asemonea santinagarensis: Logunov, 2004: 74 (Transfer from Lyssomanes).

TYPE. INDIA: Holotype $q$ of Lyssomanes santinagarensis (ZSI) from Santinagar, Palta, North 24-Parganas Dist., West Bengal, India, 1992, Biswas \& Biswas.

OTHER MATERIAL. INDIA: $1 \sigma^{7}$ (CATE, 8708A), Kerala, Wayanad Distr., Sulthan Bathery Range, Wayanad Wildlife Sanctuary $\left(11^{\circ} 41^{\prime} 26.4^{\prime \prime} \mathrm{N}, 76^{\circ} 21^{\prime} 11.9^{\prime \prime} \mathrm{E}\right), 915 \mathrm{~m}$ a.s.1., 29.05.2016, P.P. Sudhin \& K.S. Nafin; 1 क (CATE, 8708B), the same locality $\left(11^{\circ} 41^{\prime} 07.0^{\prime \prime} \mathrm{N}, 76^{\circ} 21^{\prime} 19.4^{\prime \prime} \mathrm{E}\right), 888 \mathrm{~m}$ a.s.1., 29.05.2016, P.P. Sudhin \& K.S. Nafin.
DIAGNOSIS. The male of A. cristata can be easily distinguished from its congeners by the shape of the palpal femoral apophysis, which is ramified with a stout basal region, almost fork-like in the retrolateral view, and also by the two peg-like spines on the dorsal tibial apophysis (Figs $11,13-14,18)$. The female is close to that of A. ornatissima Peckham, Peckham et Wheeler, 1889, but can be separated by the epigyne having the lateral concave depressions and lacking the anterior shallow depression (lateral depressions absent and the anterior shallow one present in A. ornatissima) (cf. Figs 15, 19, 24 with figs 17A-D in Wanless [1980]).

REMARKS. During the three year spider survey period in the Wayanad Wildlife Sanctuary, two Asemonea species (A. cristata and A. tenuipes) were collected. Of them, A. tenuipes was the commonest, yielding 120 collected specimens (74 00 and $\left.46 \bigcirc^{7} \bigcirc^{7}\right)$ from the study area. Yet, only three individuals $\left(2 \circ 9\right.$ and $\left.1 \sigma^{7}\right)$ of $A$. cristata were collected during the same study period. A pair of $A$. cristata was collected together, however the female is not included in the studied material listed above because it was damaged due to bad preservation. Thus, there is no doubt that the current matching of the male and the female of A. cristata is correct.

SYNONYMY JUSTIFICATION. Thorell [1895] described Asemonea picta on the basis of two females and $A$. cristata from a single male, all collected from Tharrawady in Burma (now Myanmar). However, he suspected that A. picta 


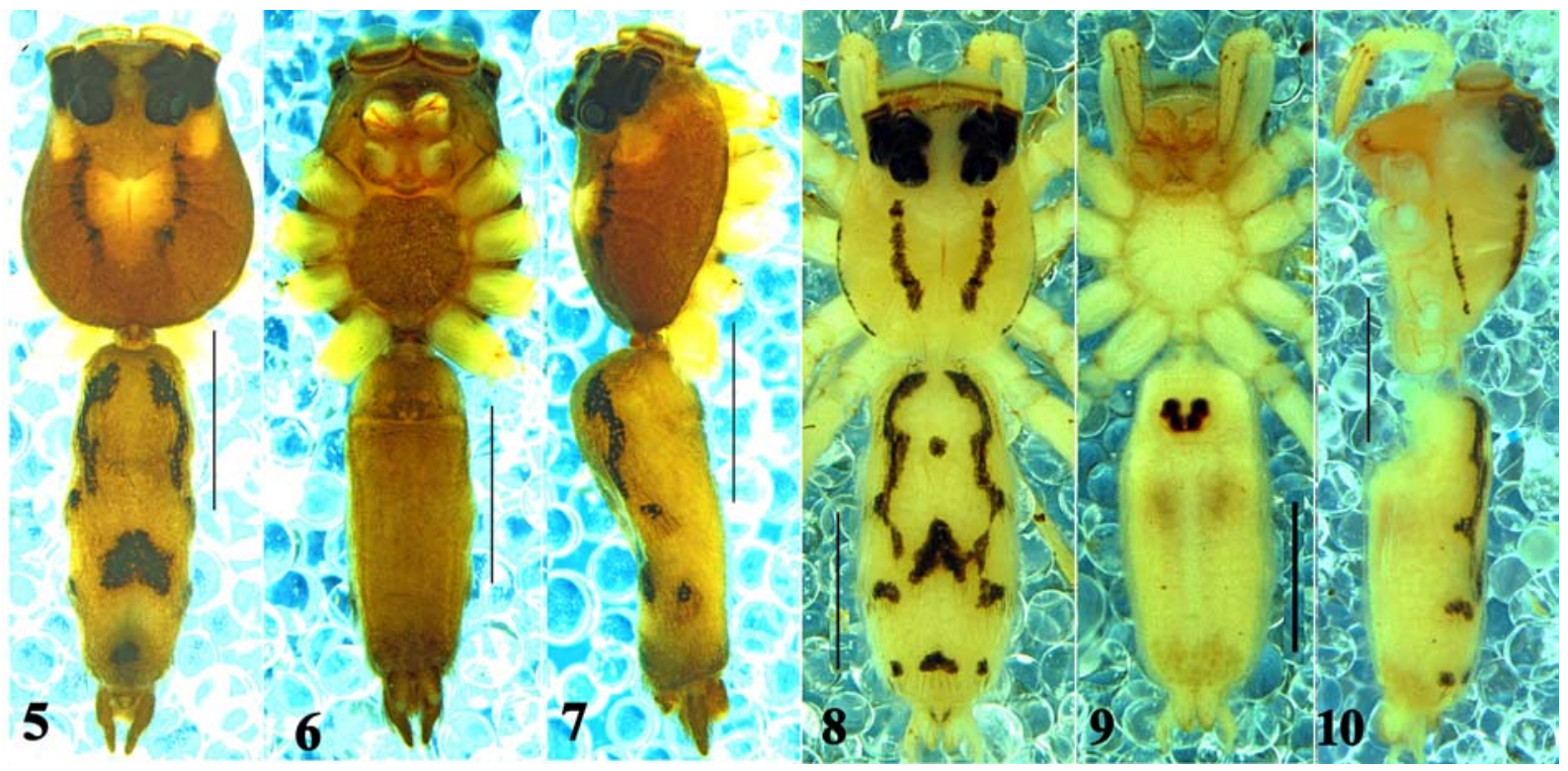

Figs 5-10. General appearance of Asemonea cristata Thorell, 1895: 5 - male, dorsal view; 6 - ditto, ventral view; 7 - ditto, lateral view; 8 - female dorsal view; 9 - ditto, ventral view; 10 - ditto, lateral view. Scale bars: (5-10) $1 \mathrm{~mm}$.

Рис. 5-10. Общий вид Asemonea cristata Thorell, 1895: 5 - самец, вид сверху; 6 - то же, снизу; 7 - то же, сбоку; 8 - самка, вид сверху; 9 - то же, снизу; 10 - то же, сбоку. Масштаб: (5-10) 1 мм.
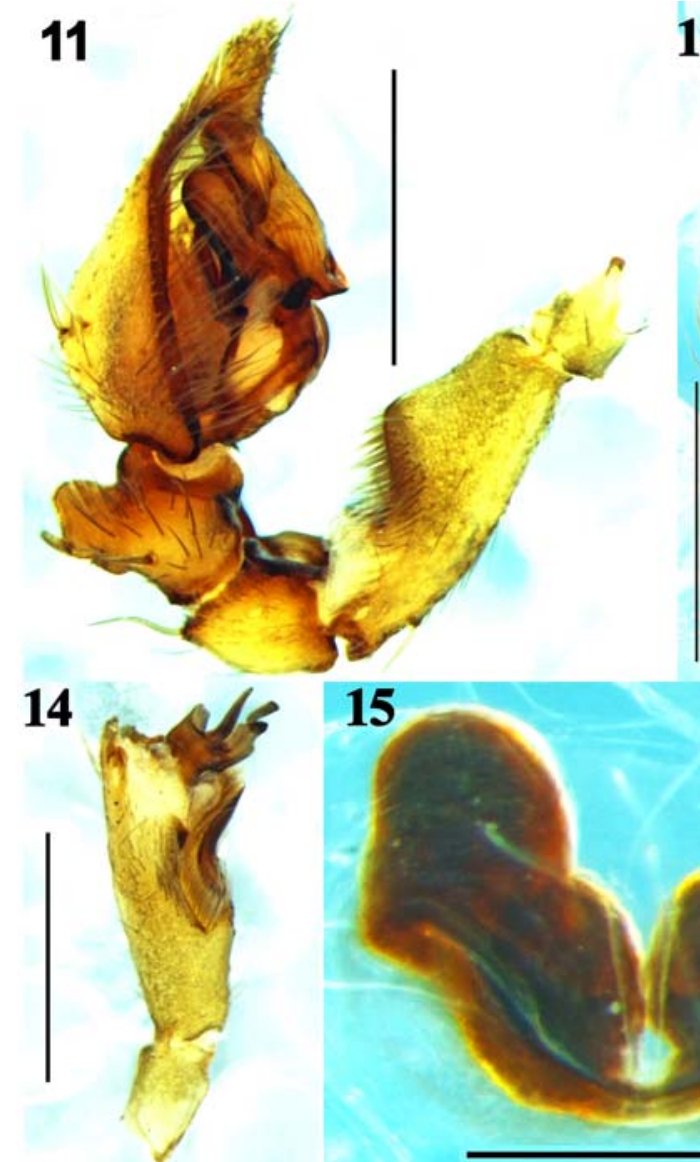

12

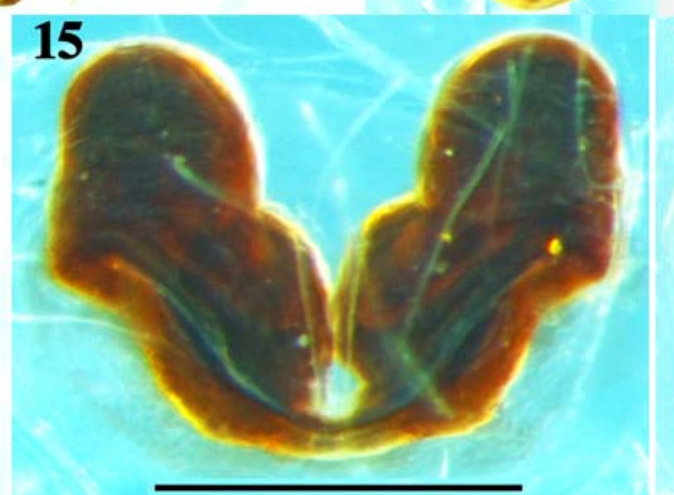

13

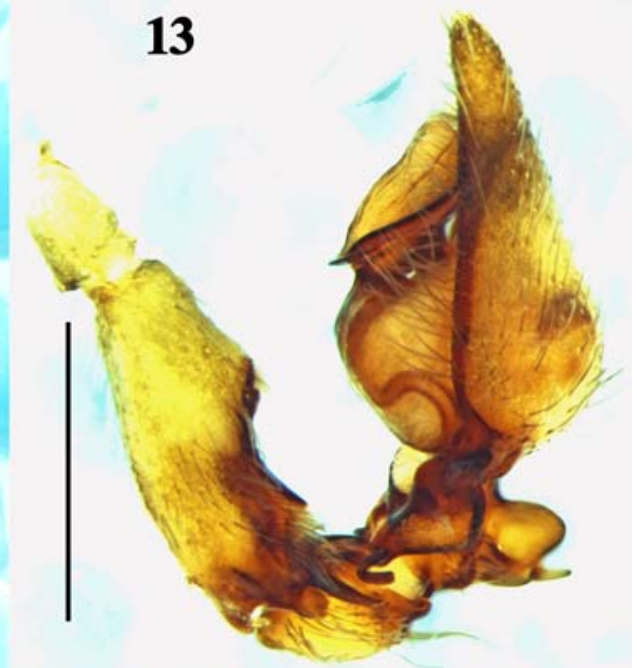

16

Figs 11-16. Copulatory organs of Asemonea cristata Thorell, 1895: 11 - left male palp, prolateral view; 12 - ditto, ventral view; 13 - ditto, retrolateral view; 14 - palp femur, prolateral view; 15 - epigyne, ventral view; 11 - vulva, dorsal view. Scale bars: (11-14) $0.5 \mathrm{~mm},(15-16) 0.2 \mathrm{~mm}$.

Рис. 11-16. Копулятивные органы Asemonea cristata Thorell, 1895: 11 - левая пальпа самца, вид сбоку-сзади; 12 - то же, снизу; 13 - то же, сбоку-сзади; 14 - бедро пальпы, сбоку-снизу; 15 - эпигина, вид снизу; 11 - вульва, вид сверху. Масштаб: (11-14) 0,5 мм, (15-16) 0,2 мм. 


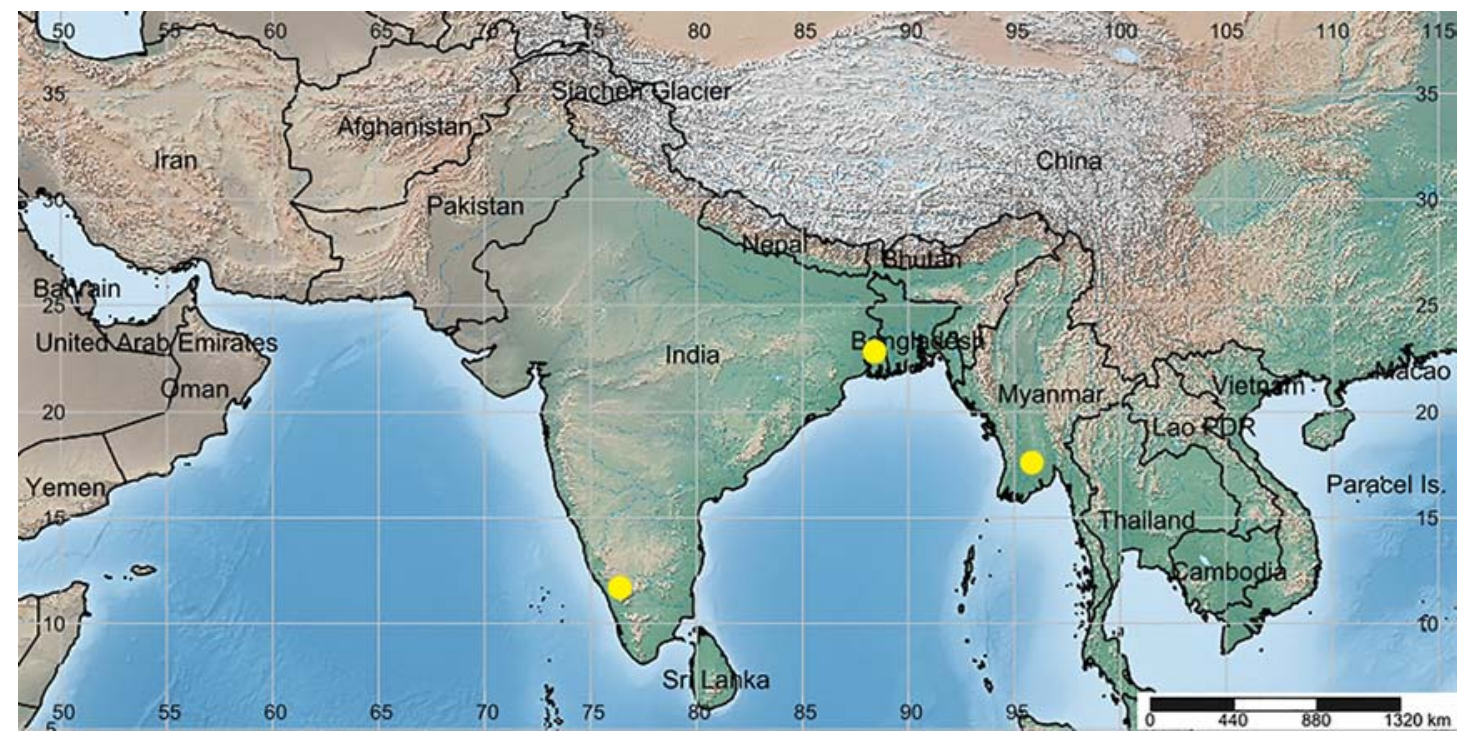

Map. Collecting localities of Asemonea cristata Thorell, 1895.

Карта. Точки находок Asemonea cristata Thorell, 1895.

could be conspecific with $A$. cristata or A. tenuipes (O. Pickard-Cambridge, 1869). The same type locality of $A$. picta and A. cristata could have also prompted Wanless [1980] to share similar doubts. However, he restrained from the synonymy of $A$. picta with $A$. cristata, referring to the differences in the carapace shape between two sexes. Yet, he also doubted whether this difference could be an artefact of preservation. The freshly collected specimen confirms the sex matching of $A$. cristata and A. picta. The general morphology, colour pattern and genital morphology are identical to those illustrated by Wanless [1980] (cf. Figs 3-5, 8$10,15-16,19-20$ with figs $20 \mathrm{~A}-\mathrm{C}$ in Wanless [1980]). Thus, there is no doubt that the names $A$. picta and $A$. cristata are conspecific, and the former is to be regarded as a junior synonym of the latter.

Biswas \& Biswas [1992: sub Lyssomanes s.] described $A$. santinagarensis from a single female collected from Santinagar district in West Bengal, India. A detailed re-examination of the holotype shows that it has all of the diagnostic characters of $A$. cristata including the heavily sclerotized and peanut shell-shaped vulva and the epigyne having a dark heavily sclerotized wide U-shaped projection, two wide lateral concave depressions and the small atrium located posteriorly (cf. Figs 8-10, 15-16, 19-20 with figs 17-19 in Biswas \& Biswas [1992]). Therefore, it is safe to conclude that the name $A$. santinagarensis is to be synonymised with $A$. cristata.

DISTRIBUTION. Three localities from India and Myanmar (Map).

DESCRIPTION. MALE (Figs 1-2, 5-7, 11-14, 17-18). Measurements: body length 3.82. Carapace length 1.67, width (at the middle) 1.29, Abdomen length 2.03, width (at the middle) 0.72 . Ocular area length 0.61 , width 0.93 . Eye diameters: AME 0.36, ALE 0.17, PME 0.13, PLE 0.15. Clypeus height 0.16 . Length of chelicera 0.38 . Palp and leg measurements: palp $1.64[0.52,0.24,0.21,0.67]$, leg I $5.16[1.51$, $0.45,1.48,1.32,0.40]$, II 4.70 [1.42, $0.38,1.28,1.17,0.45]$, III 5.03 [1.41, 0.42, 1.22, 1.45, 0.53], IV 5.71 [1.53, 0.30, $1.36,1.87,0.65]$. Leg formula: 4132. Spination. Palp: femur pl 1 patella pl 1 tibia do 2 rl 2. Legs: femur I-IV do 3 pl $1 \mathrm{rl}$ 1; patellae I-IV spineless; tibia I-II do 2 pl 1 rl 1 plv 5 rlv 5 , III-IV do 2 pl 2 rl 2 plv 3 rlv 2; metatarsi I-II do 1 pl 1 rl 1 plv 4 rlv 4 , III pl 3 rl 2 plv 3 rlv 2, IV pl 4 rl 3 plv 2 rlv 2; tarsi I-IV spineless. General appearance as in Figs 1-2, 5-7. Carapace pear-shaped, moderately high, greenish brown, with light brown setae; ocular region and space behind PLEs light greyish brown, laterally with a pair of pale yellow patches (Fig. 5); ocular region covered with fine white hairs; thorax mediolaterally with a pair of black longitudinal curved streaks, space between streaks pale yellow (Fig. 5); clypeus greenish brown, about a half AME diameter, covered with white fine hairs; chelicerae light green, laterally pale, promargin with two teeth and retromargin with five teeth; endites light green, inner region pale (Fig. 6); labium light green, distally pale yellow, with few curved brown setae (Fig. 6); sternum greenish brown, with indistinct margins (Fig. 6). Abdomen slender, ovoid, light green, covered with black and light brown setae, anterolaterally with a pair of thick irregular black longitudinal markings, laterally with two pairs of black spots, medially with a thick inverted Vshaped black marking, posteriorly with a black medial marking (Fig. 5). Venter light green, covered with short white setae, the region near pedicel darker (Fig. 6). Pedicel light greenish brown, covered with brown and white setae (Figs 5-7). All legs creamy-yellow. Leg I retrolaterally with a greenish stripe extending from femur to tarsus. Leg II retrolaterally with a greenish stripe on femur and patella. Leg IV retrolaterally with a greenish stripe on femur and tibia. All tibia retrolaterally with proximal and distal black mottlings. Palp as in Figs 11-14, 17-18. Palpal segments light yellowish; femur with ventral furrow and apical apophysis, apical apophysis ramified with a stout basal region, almost forklike in the retrolateral view, one branch with a U-shaped bend at its tip (Figs 13, 18); patella distally with an elongated dorsal spine (Figs 11, 13, 18); tibia distally with a small finger-like prolateral apophysis; RTA broad with tapering ends (Figs 13, 18), dorsal apophysis stout with two peg-like spines (Figs 11, 13, 18); cymbium oval, distally tapering, covered with long setae (Figs 11-13, 17-18); embolus long, slender, whip-like, arising from the posterior margin of tegulum; tegulum ovoid in the ventral view, with a distal flange (Figs 12, 17); subtegulum bulbous, with a sinuous duct (Figs 12, 17). 


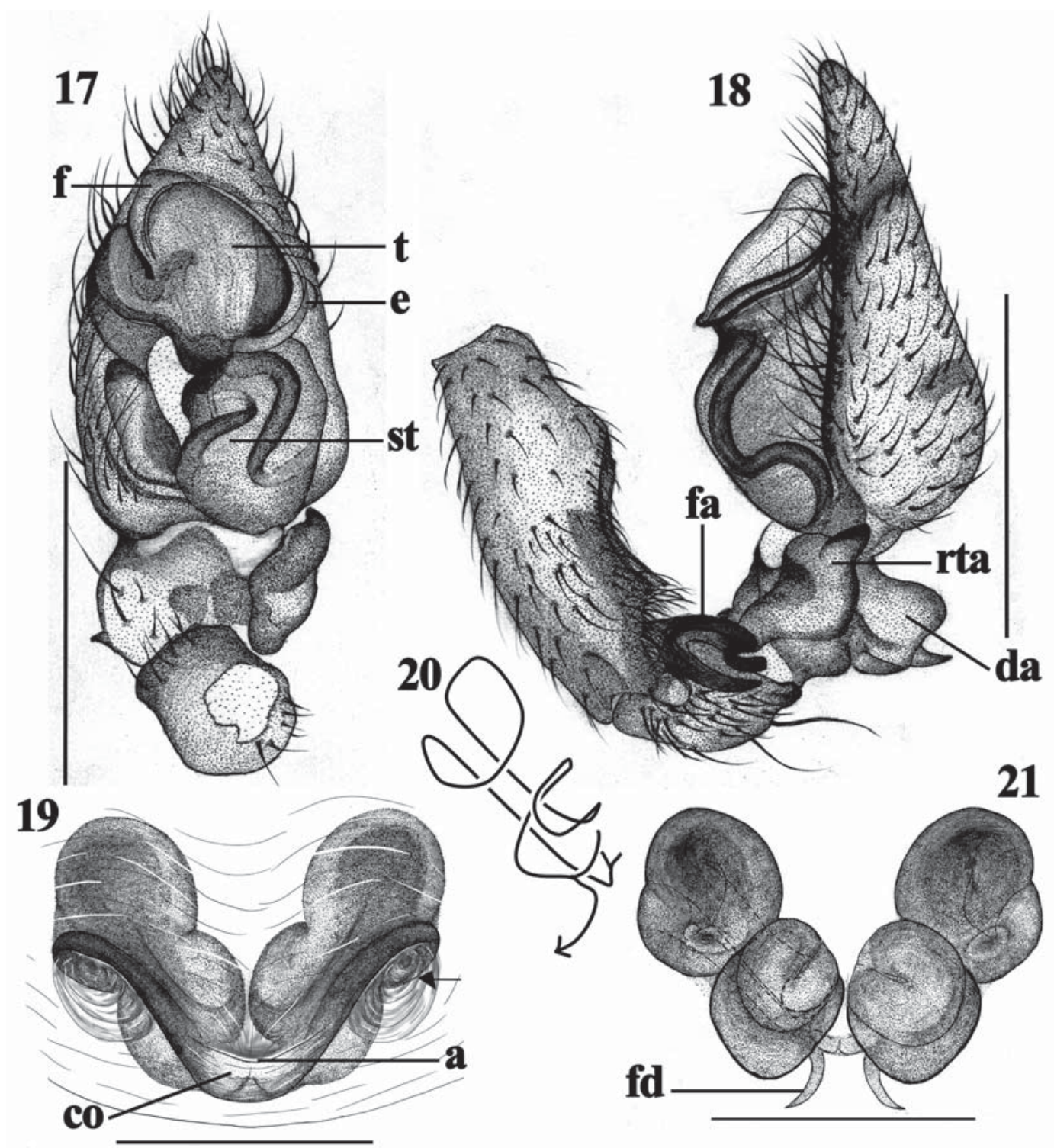

Figs 17-21. Copulatory organs of Asemonea cristata Thorell, 1895: 17 - left male palp, ventral view; 18 - ditto, retrolateral view; 19 - epigyne, ventral view; 20 - diagrammatic course of insemination ducts; 21 - vulva, dorsal view. Scale bars: (17-18) $0.5 \mathrm{~mm}$, (19, 21) $0.2 \mathrm{~mm}$. Abbreviations as explained in 'Material and methods'.

Рис. 17-21. Копулятивные органя Asemonea cristata Thorell, 1895: 17 - левая пальпа самца, вид внизу; 18 — то же, сбокусзади; 19 - эпигина, вид снизу; 20 - схема протоков копулятивных канальцев; 21 - вульва, вид сверху. Масштаб: (17-18) 0,5 мм, $(19,21) 0,2$ мм. Сокращения, как объяснено в 'Материалах и методах'.

FEMALE (Figs 3-4, 8-10, 15-16, 19-21, 22-25). Measurements: body length 4.22 . Carapace length 1.76 , width (at the middle) 1.28, Abdomen length 2.40, width (at the middle) 1.02. Ocular area length 0.61, width 1.02. Eye diameters: AME 0.37, ALE 0.17, PME 0.13, PLE 0.14. Clypeus height 0.16 . Length of chelicera 0.43 . Palp and leg measurements: palp 1.69 [0.60, 0.21, 0.31, 0.57], leg I 5.51 [1.61, $0.53,1.61,1.36,0.40]$, II 4.95 [1.51, 0.50, 1.35, 1.18, 0.41], III $5.56[1.60,0.39,1.47,1.53,0.57]$, IV $6.78[1.80,0.43$, $1.80,2.13,0.62]$. Leg formula: 4312. Spination. Palp: patella do 1 tibia pl 2 tarsus do 3 pl 2 rl 2 plv 1 rlv 1 . Legs: femur I-IV do $3 \mathrm{pl} 1 \mathrm{rl}$ 1; patellae I-IV spineless; tibia I-II pl $1 \mathrm{rl} 1$ plv 5 rlv 5 , III do 1 pl 2 rl 1 plv 2 rlv 1 , IV do 2 pl 2 rl 2 plv 2 rlv 2; metatarsus I plv 4 rlv 4, II pl 1 rl 1 plv 4 rlv 4, III-IV pl 3 rl 3 plv 2 rlv 2; tarsi I-IV spineless. General appearance as in Figs 3-4, 8-10. In all respects as the male, except as follows: carapace creamy-yellow, its margins with a black line extending from coxae II to IV, mediolateral longitudinal streaks more straightened (Fig. 8); clypeus creamy-white, with long white setae; chelicerae light yellow (Fig 10); endites and labium creamy-yellow (Fig. 9); sternum creamywhite (Fig. 9); abdomen creamy-white, more robust, anterolateral longitudinal irregular markings reaching to an inverted V-shaped patch, anteromedially with a round black spot, inverted V-shaped markings more clear and linear, posterolaterally, with a pair of black markings (Fig. 8); venter creamy-white, without any prominent markings (Fig. 9); spinnerets creamy-white; all legs light yellowish, all tibia 


\section{2

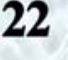

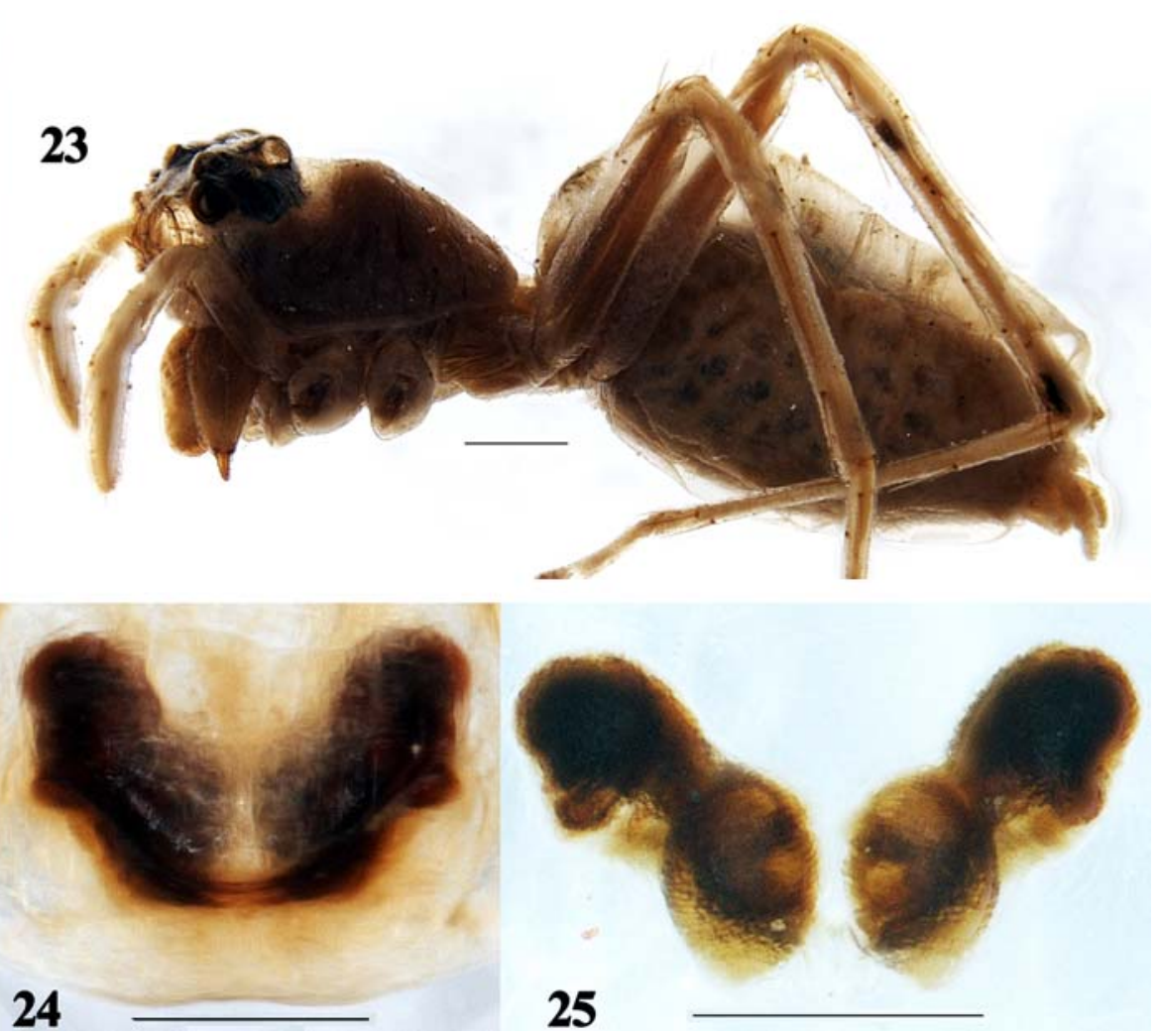

Figs 22-25. Asemonea cristata Thorell, 1895 (the holotype of Lyssomanes santinagarensis Biswas et Biswas, 1992): 22 - female dorsal view; 23 - ditto, lateral view; 24 - epigyne, ventral view; 25 - vulva, dorsal view. Scale bars: (22-23) $0.5 \mathrm{~mm},(24-25) 0.2 \mathrm{~mm}$.

Рис. 22-25. Asemonea cristata Thorell, 1895 (голотип Lyssomanes santinagarensis Biswas et Biswas, 1992): 22 - самка, вид сверху; 23 - тоже, сбоку; 24 - эпигина, вид снизу; 25 — вульва, вид сверху. Масштаб: (22-23) 0,5 мм, (24-25) 0,2 мм.

retrolaterally with proximal and distal black mottlings. Epigyne as shown in Figs 15-16, 19-21, 24-25. Epigyne with a dark, highly sclerotized wide U-shaped projection, laterally with concave depressions below the projection (arrowed in Fig. 19); atrium small, undivided, posteriorly located, opening anteriorly (Figs 15, 19); copulatory openings closely placed; vulva heavily sclerotized, peanut shell-shaped; spermathecae separated from each other; insemination duct with four loops, entering the spermathecal reservoir posteriorly (Figs 20-21); fertilization duct located posteriorly (Figs 16, 21).

Acknowledgements. We are grateful to Dr Mathew Paul Ukken, the Principal of the Christ College (Autonomous), Irinjalakuda, Kerala, for allowing us to use their research facilities. We thank Dr Kailash Chandra, Director of the Zoological Survey of India, Kolkata for allowing us to reexamine the holotype of Lyssomanes santinagarensis. The authors are grateful to Mr Dhanesh Kumar P., Wildlife Warden, and the field staff of the Wayanad Wildlife Sanctuary, especially to Mr Krishnadas K. Rajan, Assistant Wildlife Warden, Mr Suresh Thenarambath, Forester and $\mathrm{Mr}$ Appu, Field Watcher for the hospitality and support during fieldworks. This study was funded by the Science \& Engineering Research Board (SERB) DST, New Delhi, under the Young Scientist Research Project: No. SB/YS/LS-86/2013. We are grateful to Dr Dmitri V. Logunov of the Manchester
Museum (UK) for his editorial help and to anonymous reviewers for their help with improving the ms.

\section{References}

Biswas B., Biswas K. 1992. Araneae: Spiders // State Fauna Series 3: Fauna of West Bengal. No.3. P.357-500.

Bonnet P. 1955. Bibliographia Araneorum. Toulouse: Imprimerie Douladoure. T.2. Pt.1. 918 pp.

Bosselaers J., Jocqué J. 2000. Studies in Corinnidae: transfer of four genera and description of the female of Lessertina mutica Lawrence 1942 // Tropical Zoology. Vol.13. P.305-325.

Sherriffs W.R. 1931. South Indian Arachnology. Part V // Ann. Mag. nat. nat. Hist. Ser.10. Vol.7. P.537-546.

Simon E. 1901. Histoire naturelle des araignées. Deuxième édition. T.2. Paris: Roret. P.381-668.

Thorell T. 1895. Descriptive catalogue of the spiders of Burma. London. $406 \mathrm{pp}$.

Wanless F.R. 1980. A revision of the spider genera Asemonea and Pandisus (Araneae: Salticidae) // Bulletin of the British Museum of Natural History (Zool.). Vol.39. P.213-257.

Wesołowska W. 2009. A new species of Asemonea from Zambia (Araneae: Salticidae: Lyssomaninae) // African Zoology. Vol.44. P.126-128.

WSC 2019. World Spider Catalog. Natural History Museum Bern, online at: http://wsc.nmbe.ch, version 20.5 (accessed on 6th March 2020).

Responsible editor D.V. Logunov 